\title{
UNPACKING NIGERIA'S PEACE EFFORTS DURING THE SECOND CYCLE OF THE LIBERIAN CONFLICT
}

Segun Oshewolo'

\section{Introduction}

Post-colonial Nigeria has become a major player in the prevention, management, and resolution of international conflicts. Peace operations represent a major component of Nigeria's general foreign policy, which emphasizes national interest, world peace, friendship and cooperation. Nigeria's participation in international peace operations officially began at independence when the country took part in the Congo peace mission under the umbrella of the United Nations (UN) (Obasanjo 2007; Akintola 2007; Agbu 2007). From that point, Nigeria has been involved in the various levels of international peace operations. These include deployments under the platforms of the UN, Organization of African Unity/African Union (OAU/AU), Economic Community of West African States (ECOWAS) and the ECOWAS Monitoring Group (ECOMOG), and other bilateral arrangements. Nigeria was involved in the peace processes in Lebanon, Chad, Angola, Namibia, Cambodia, Yugoslavia, Somalia, Rwanda, Liberia, Sierra Leone, among others (Alli 20I2). Through the years, 'Nigeria has deployed forces of various strength ranging from observer missions usually made up of a few men and smaller sized units to battalions and division-sized forces' (Oluyemi-Kusa 20I2, p. I37).

As explained by Akintola (2007, p. 77), Nigeria's role in international peace operations has 'shifted qualitatively from that of a participant to initiator'. The reason is that the country has not only featured prominently in UN peace operations, but has succeeded in spearheading peace operations in

\footnotetext{
I The author lectures in the Department of Political Science and International Relations, Landmark University, Omuaran, Nigeria. The author has published widely in his areas of research interest which include foreign policy and diplomacy, democratisation, environmental politics and gender studies. His recent articles appeared in The Round Table and African Identities - both Scopus-indexed journals. E-mail: segunoshewolo@yahoo.com
} 
Africa by mobilizing other countries in the region. Nigeria's peace missions in Africa normally involve mediators, the Nigerian police force, and members of the armed forces (Gbor 2007; Musa 2010). The Nigerian Army as a component of the Nigerian Armed Forces 'has borne the greatest burden of peace operations to which Nigeria, and by extension the Nigerian military, has been invited since the country's independence in I960' (Gbor 2007, p. 6I). In Africa, Nigeria's approach to regional security has been largely influenced by its national role conception in continental international relations. With this role conception, Nigerian political leaders understand the country as a natural leader in Africa with the responsibility to promote and protect the interests of the continent (Alli 20I2; Oshewolo 20I8; Saliu \& Oshewolo 20I8). In addition, the security of Nigeria is believed to be tied to that of other African states fundamentally because of cultural and historical linkages (Alli 20I2).

Following the closure of the Mission in Liberia on March 302018 after I5 years deployment and president Olusegun Obasanjo's recognition of Nigeria as a leading actor in the stabilization efforts in the region, it is important to conduct a study of the role played by Nigeria in the Liberian peace process under the banners of the United Nations Mission in Liberia (UNMIL) and ECOWAS Mission in Liberia (ECOMIL). After years of military dictatorships and the consequent disorientation of Nigeria's Africa diplomacy, the emergence of President Obasanjo on 29 May I999 as the democratically elected leader ushered the country into a new era of diplomatic renaissance in Africa. His administration was expected to oxygenate Nigeria's Africa diplomacy and make meaningful contributions towards addressing the security challenges confronting the continent. Liberia - Nigeria's West African neighbor - was one of the countries going through internal political convulsion at the time. Considering the desire of President Obasanjo - expressed through his foreign policy speeches - to address head-on Africa's security concerns, this study is designed to examine the effectiveness of Nigeria's peace campaigns during the second cycle of the Liberian conflict. To carry out this task, the paper adopted the secondary sources and interview technique for the purpose of data collection. The key-informants were selected using the purposive sampling procedure ${ }^{2}$. The method of data analysis is descriptive thematic analysis.

2 The study's key-informants include Ambassador (Professor) Akinjide Osuntokun (Honorary Adviser on Foreign Policy to President Olusegun Obasanjo and a member of the Presidential Advisory Council on International Relations), Ambassador (Professor) Alaba Ogunsanwo (Department of International Relations, Lead City University, Ibadan, Oyo State), Captain Sadeeq Garba Shehu (Nigeria's Ministry of Defence and the AU Commission, Addis Ababa, Ethiopia), Ambassador Jaiyeola Joseph Lewu (Retired Ambassador and principal actor in the West African peace processes under President Obasanjo), Professor Osisioma Nwolise (Department of Political Science, University of Ibadan), Professor Alade Fawole (Department 


\section{President Obasanjo's peace rhetoric in Africa}

To make sense of Nigeria's peace efforts in Africa under president Olusegun Obasanjo, the study focused on some of his foreign policy speeches while in office. These speeches offered valuable insights into President Obasanjo's foreign policy position towards Africa. The use of verbal ornamentation by a leader, particularly through foreign policy speeches, is suggestive of the leader's convictions and idiosyncrasies about how government or international relations should be organized. Although historical evidence may suggest that what leaders 'say' does not always translate into what leaders 'do', the speeches of the leader and the views expressed through them are largely considered as the official reflection of national policy. They are also largely a good indicator of foreign policy positions (Fawole 2000; Oshewolo 20I8). Through his foreign policy speeches in both African and extra-African fora, President Obasanjo clearly expressed the commitment of his administration to Africa's peace and stability. Therefore, a major component of Nigeria's Africa diplomacy under Obasanjo was the promotion of peace and stability (Ogunsanwo 20I6; Fawole 20I6; Akinboye 20I6; Ajayi 20I6; Osuntokun 20I6).

Shortly after his emergence as Nigeria's president in I999, Chief Obasanjo described Africa as a continent ravaged by conflicts, and where the sound of guns was more audible than the voice of reason. He made it clear to other African leaders that it would be morally reprehensible to stand idly and allow people to continue to suffer on account of these problems (Obasanjo I999). During the United Nations' millennium summit in New York in 2000, Obasanjo expressed his disgust about the persistence of conflicts on the continent. He observed that these conflicts had been very devastating as a result of the destruction of lives and key infrastructure, and their deleterious effects on the weaker members of society such as children and women (Obasanjo 2000a). At another forum, Obasanjo observed that of all the predicaments facing the continent, the most intractable had been the proliferation of internal conflicts. These conflicts had imposed heavy social and economic costs on governments, created the burden of refugee flows, disrupted economic activities and investment flows due to the general climate of fear associated with conflicts (Obasanjo 200ob).

President Obasanjo maintained that the nations of Africa could not develop if domestic conflicts were not properly managed. He observed that the problems of security and stability would impair the capacity of African

of International Relations, Obafemi Awolowo University, Ife), Professor Solomon Akinboye (Department of Political Science, University of Lagos), Professor Kunle Ajayi (Department of Political Science, Ekiti State University, Ado-Ekiti). 
nations to achieve integration and socio-economic transformation (Obasanjo I999). For him, peace is not only vital for interstate cooperation; it is also an essential condition for development (Obasanjo 200ob). While delivering his acceptance speech after his election as the chairman of the AU in 2004, he noted that the body would confront headlong the conflict situations in Africa with renewed vigor and determination (Obasanjo 2004).

Again, after ceding Bakassi Peninsula to Cameroon following the judgment of the International Court of Justice (ICJ), president Obasanjo maintained that Nigeria honored the ICJ judgment, despite its wide condemnation within the country, to promote peace, security and stability. With this singular decision, he claimed that Nigeria had set a lesson for Africa and the world. Nigeria had demonstrated the possibility of resolving a difficult border problem without war. Nigeria had demonstrated the values of accommodation, tolerance, dialogue and commitment to peace (Obasanjo 2006). On account of Nigeria's good neighborliness and big-brother role in the West African sub-region, the administration of president Obasanjo was even more concerned with the security situation in West Africa (Alli 20I2; Oshewolo 20I8). To examine the effectiveness of the administration's peace efforts in Africa, the study focused on Nigeria's West African Neighbor - Liberia.

\section{The second cycle of the Liberian conflict}

The first Liberian civil war began in I989. In response to the conflict, President Babangida sent 'Nigerian troops there as the bulk of an ECOWAS Monitoring Group (ECOMOG) to end a war between President Samuel Doe's regime and rebels led by Charles Taylor'. Following the death of Doe and the control of much of the country by Taylor, Nigeria was 'obliged to accept a presidential election' in which Taylor won a majority of votes (Lliffe 20II, p. 2I8). Therefore, the rebellion against the oppressive rule of Samuel Doe ended with the election of Charles Taylor (a principal actor in the war) as the President of Liberia on August 6, I997. The fact that Taylor (the leader of NPFL rebel forces) participated in the election and emerged victorious confirmed the neutrality and impartiality of the Nigeria-led ECOMOG peacekeeping force in Liberia. He was not only allowed to win the election and sworn in as President, he was also protected by the same ECOMOG troops he attacked during the war. This was a demonstration of a high moral standard in international peacekeeping (Nwolise 2007).

The diverse narratives that provide explanations for the first cycle of the conflict have received a sizeable coverage in the literature (Johnson Sirleaf I99I; Munive 20II; Kieh 20I2; Call 20I0; Boas 20I4). The focus of this study 
however is on the second cycle of the war which began on April 2I, I999. The celebrated peace that heralded the electoral victory of Charles Taylor by a landslide of 75 per cent in a relatively free and fair election soon collapsed like a stack of cards (Call 20IO). At the inauguration of President Olusegun Obasanjo as Nigeria's President on May 29, I999, the second Liberian civil war had lasted for only thirty-nine days. The onus was therefore on Obasanjo's government to restore peace in war-torn Liberia (Fawole 2016). Kieh (2009, p.8) offered a concise background to the second Liberian civil war. In his submission;

The war commenced with armed attacks launched by a warlordist militia, Liberians United for Reconstruction and Democracy (LURD). The outfit was an amalgam of members of some of the erstwhile militias that were involved in the first Liberian civil war, disaffected members of the former Taylor-led National Patriotic Front of Liberia (NPFL), and war-time capitalists with interests in the private accumulation of capital. LURD launched its attacks from Guinea, Liberia's neighbor to the North... In March 2003, the ambit of the war was broadened when the Movement for Democracy in Liberia (MODEL), a surrogate organization of LURD, joined the war against Taylor. MODEL launched its armed attacks from Cote d'Ivoire, Liberia's Eastern neighbor.

The author also identified the factors that precipitated the crisis. The proximate factors, which were the direct undercurrents of the crisis, had to do with Charles Taylor's miserable performance in office. This reflected in the convergence of issues such as 'ethnic-scapegoating', political repression and economic malaise. Then again, the contingent factors were necessary but not sufficient conditions for the crisis to take place. These included the failure to properly disarm, demobilize, rehabilitate, and re-integrate the ex-combatants into the larger society; the failure to embark on a meaningful security sector reform; and the refusal of the Taylor administration to set in motion the process of addressing the underlying causes of the first civil war (Kieh 2009). As articulated by Yoroms (2005), these rebel groups also believed that Taylor did not win the election fairly. They claimed that Taylor emerged victorious through a special arrangement by ECOWAS.

Explaining the precipitants further, George (20I2) remarked that Charles Taylor failed to utilize his election as President to properly transform himself from a warlord to a responsible head of state. The thinking initially was that the election of Taylor would offer opportunities for peace. The electoral victory of Taylor - who was a principal actor in the crisis - was expected to put an end to the conflict and allow ECOMOG to complete the final tasks 
of disarming, demobilizing, training, reorganizing and reintegrating the rebels into the Liberian armed forces. These opportunities were however squandered (Yoroms 2005). He engaged in political rascality, provided supports for rebels and dissidents in Sierra Leone and Guinea primarily to motorize his illegal trade in diamonds, and therefore became the locus of the conflict in the Mano River region (Gambari 2005; George 20I2; Nwolise 2016). Taylor demonstrated that his intention was not only to rule Liberia but also to control regimes in the Mano River region and build an empire for himself in the region (Yoroms 2005). The combination of the proximate and contingent factors made Liberia's regression into the abyss of war inevitable. It may be hard to remember now, but Taylor's war (his dissidence during the first cycle of the crisis and his violent oppression during the second cycle) was beastly and produced an immense humanitarian disaster (Lizza 2005).

\section{Motivations for intervention}

The data sources revealed that the government of President Olusegun played frontline roles in restoring peace to Liberia (Nwolise 2016; Fawole 20I6; Ajayi 20I6; Shehu 20I8; Lewu 2018). Although Nigeria's intervention hugely defined the outcome of the conflict in Liberia, it must be noted that the government of President Obasanjo was initially wary of deploying Nigerian troops. This cautious attitude can be explained. Nigeria was at the beginning disinclined to troop deployment because of the enormous cost that accrued to the country during the first cycle of the war without support from the West and the loss of hundreds of Nigerian soldiers that made the intervention unpopular at home (BBC News, August 4, 2003; Shehu 2018).

Again, in spite of ECOMOG's stabilizing role in Liberia, Taylor refused to honor the mandate allowing ECOMOG to remain in Liberia to perform the post-war reorganization of the Liberian military (Lewu 20I8). After he became president, he ordered ECOMOG out of Liberia and Nigeria-led ECOMOG departed without accomplishing the final mission of the peacekeeping process (Yoroms 2005). Taylor's expression of disapproval for ECOMOG's continuing stay in Liberia led to the departure of the last batch of Nigeria's ECOMOG troops in I999. These troops - numbering about 60 - arrived at the Abuja airport in October I999 and were received by Dupe Adelaja - Nigeria's Minister of State for Defense - and other top army officers (Independent Online, I999). Taylor's attitude therefore put off President Obasanjo's interest in the second Liberian civil war initially (Yoroms 2005). President Obasanjo was also of the view that the international community had the duty to intervene in Liberia. As such, the conflict was not a problem to be resolved by ECOWAS 
alone (Yoroms 2005). However, as the situation during the second Liberian civil war degenerated and the international community failed to intervene, Nigeria was forced to respond by sending the first batch of troops to support mediation efforts, stop an unfolding humanitarian disaster in Liberia and the spread of the conflict to neighboring states that were already burdened with a steady stream of refugees from the Liberian civil war (Dukule 2005; Obi 2009; Lewu 20I8; The Liberian Connection, nd). Nigeria's cautious attitude about peace operations in Liberia notwithstanding, president Obasanjo's intervention was still considered very imperative for a number of reasons.

In terms of the motivations for President Obasanjo's intervention, George (20I2, p. 38I) observed that the crisis in Liberia was 'a threat and challenge to political stability, peace and security of the sub-region'. Explaining the context further, Fawole (2016), noted that if Nigeria did not get involved, it would have meant that Nigeria's initial seven years of sacrifice in manpower, resources and diplomacy during the first cycle of the war would have been wasted. This is what Shehu (20I8) referred to as the theory of 'sunk costs'. Since a lot of human and financial resources had been sunk in Liberia by the time Obasanjo assumed leadership, it was imperative and logical to make efforts to get Taylor out of power in the interest of peace. Again, as realists would argue, the government of President Obasanjo got involved in the crisis to demonstrate Nigeria's leading position or hegemonic role in the West African sub-region. In other words, the crisis in Liberia offered Nigeria the opportunity to project its military and diplomatic capabilities in the sub-region. The intervention had more to do with Obasanjo's image as a great leader, his desire to leave an indelible mark on Nigeria's history, and the aspirations of the Nigerian army to enhance its status and worth as a national and sub-regional asset (Obi 2009). As argued by Uba (2016), Nigeria used the platforms of ECOMIL and UNMIL to demonstrate its leadership credentials in Africa and diplomatic status within the international society. The intervention in Liberia by the civilian administration of Obasanjo has also been justified on the ground of promoting 'African solutions to African problems' (Obi 2009, p. I22).

\section{Nigeria's mediatory and peacekeeping efforts in Liberia}

In terms of form, Nigeria's intervention in Liberia oscillated between mediation and peacekeeping. Nigeria's mediatory efforts - which culminated in the eventual signing of a comprehensive peace agreement in 2003 - primarily involved President Obasanjo and the special mediator he appointed, General Abdulsallam Abubakar (Alli 20I2; George 20I2; Fawole 20I6; Ajayi 
20I6). President Olusegun Obasanjo deployed Nigeria's diplomatic resources to halt all offensive military actions among warring factions, and bring them to a negotiated settlement. Some of the key-informants noted that the resilience of President Obasanjo, which found expression in his cease-fire diplomacy, dotted the entire peace process. Nigeria successfully facilitated the exit of Taylor from power, supervised the comprehensive peace agreement, offered Taylor a temporary sanctuary in Nigeria, and supported the 2005 post-conflict elections (Osuntokun 20I6; Fawole 20I6; Nwolise 20I6; Lewu 20I8). In March 2002, as part of Nigeria's mediatory efforts, Abuja hosted a Preparatory Meeting to the Liberian National Reconciliation Conference (LNRC). The meeting was designed as an assembly of government officials, rebel leaders and Liberian civil society groups to strengthen the country's efforts, and as a precursor to the All Liberian Reconciliation Conference scheduled to hold in Monrovia later in the year. The meeting had in attendance President Olusegun Obasanjo, the representative of Abdoulaye Wade (the Chairman of ECOWAS), Dr Mohamed Ibn Chambers (Executive Secretary of ECOWAS) and other notable figures (The Perspective 2002; George 2012).

The meeting was however marred by the absence of President Taylor and other rebel leaders. While Nigeria provided an aircraft to lift the officials of President Taylor to Abuja, he was lukewarm to the offer. Taylor's lukewarm attitude can be explained. Taylor and his officials erroneously believed that Nigeria was behind the international sanctions against Liberia. Yes, to introduce a draft resolution to slam international sanctions against Taylor and Liberia, the British High Commissioner and Charge d' Affaires of the United States respectively visited Ambassador Olufemi Oyewole George in his office to solicit Nigeria's support. However, Nigeria and other ECOWAS members were wary of supporting the proposal and rather opted to convince Taylor to address his political misdeeds as a matter of urgency (George 2012). Taylor's absence notwithstanding, the dialogue was significant in that it clearly marked out the germane conditions that must be satisfied before a genuine reconciliation could be achieved. These conditions included; the establishment of ceasefire between the warring parties, the effective monitoring of the national security apparatus, demobilization, rehabilitation and reintegration of dissidents, and the creation of effective mechanisms to address acts of impunity (The Perspective 2002).

As the security situation in Liberia deteriorated, ECOWAS continued its intermediation by organizing another round of peace talks in Accra on June 4, 2003 with the support of Nigeria and the international community. Before the opening ceremony, the ECOWAS Heads of Government in attendance held a private discussion with Taylor during which he was frankly repri- 
manded. After the discussion, Taylor declared that he was ready to relinquish power if he was the one obstructing the peace process (George 20I2). During the negotiations that followed, President Obasanjo sent General Abdulsallam Abubakar, former Nigerian Head of State, as special mediator supported by delegates from the UN, AU, and the United States, among others (Alli 20I2). General Abdulsallam Abubakar was instrumental in achieving the peace accord in Accra (Dukule 2005). While a ceasefire agreement was arrived at on June I7, 2003, this however broke down when the rebel forces entered the capital city of Monrovia, and again there was a regression into violence. On account of this, ECOWAS, at a summit in Dakar on July 2, 2003, resolved to deploy an ECOWAS military force to restore peace and facilitate the handover of power by Taylor. Again, on August I, 2003, the United Nations authorized the establishment of a multinational force in Liberia (Gambari 2005; George 20I2).

Before the arrival of the UN peacekeeping troops, Nigeria had deployed 300 soldiers to Liberia on August 4, 2003 (which was increased later to I,500 Nigerian peacekeepers under the banner of ECOMIL) to serve as a stabilization force, separate the belligerent forces, and support humanitarian and aid workers. As a vanguard force, ECOMIL was not to engage in enforcement but to guide or keep peace (Morgan 2003; The Perspective 2003; The Liberian Connection nd; Yoroms 2005; Alli 20I2). While the troop strength of ECOMIL was a little above 3000, Nigeria contributed about half. Other troops came from Senegal, Mali, Benin, Ghana, Gambia, Guinea Bissau and Togo. Again, Nigerian officers were given key leadership responsibilities in ECOMIL. While Brigadier-General Festus Okonkwo served as ECOMIL force commander, Colonel Mark Nyoyoko was in charge of operations (BBC News, September 9, 2003; CNN International, August 2, 2003; The Liberian Connection, nd; the Perspective 2003; United Nations 2005; Uba 2016).

Furthermore, deeply worried about the escalating conflict in Liberia, the UN Security Council (UNSC), at its 4803rd meeting on August I, 2003, adopted Resolution 1497 authorizing the deployment of a multinational force in Liberia. While I2 countries voted in favour of the Resolution, none voted against it. France, Germany and Mexico abstained from the vote. The Resolution described the situation in Liberia as a threat to international peace and to stability in West Africa, and therefore authorized the establishment of a multinational force to support the implementation of the June I7, 2003 ceasefire agreement and help maintain security in post-Taylor Liberia (United Nations Security Council 2003a; CNN International, August 2, 2003; Gambari 2005). More so, in order to provide adequate supports for humanitarian and human rights assistance, security reform and the implementation of the peace pro- 
cess, the UN Security Council, at its 4830th meeting on September I9, 2003, adopted Resolution 509 establishing the UN Mission in Liberia (UNMIL).

In fulfillment of the UNSC's request, the Secretary General of the UN transferred ECOMIL's authority to UNMIL on October I, 2003 and the former's troops transposed into UN peacekeepers (United Nations Security Council 2003b; Gambari 2005). Even under the banner of UNMIL, the Nigerian contingents remained very active and were regarded as the face of the mission (Uba 20I6). A Nigerian, Lieutenant-General Joseph Olorungbon Owonibi, who had been the Deputy Force Commander and Chief Military Observer of UNMIL since November 2003, was also appointed in 2005 as UNMIL's Force Commander by the Secretary General (United Nations 2005).

Nigeria's peace campaign in Liberia was applauded both by the Liberian people and the international community (Nwolise 20I6; Ajayi 20I6). On account of the escalation of the conflict and the failure of the international community to intervene early, the first batch of Nigerian troops deployed to Liberia was warmly received by residents of the Liberian capital, Monrovia. The presence of the Nigerian peacekeepers provided the much needed succor as the military confrontation between the government forces and rebel groups deepened (Dukule 2005; The Liberian Connection, nd). Again, Nigeria's initial intervention was significant in shaping international response to the Liberian conflict. Nigeria's initial deployment paved the way for the establishment of the UNMIL. Without such preparatory work by the Nigerian troops, it would have been difficult to get the required consensus in the Security Council to have UNMIL deployed in Liberia (African Leadership Magazine 20I6; Uba 20I6). As a measure of the warm public perception of Nigeria's foremost role in Liberia under President Obasanjo, both the ECOMIL and UNMIL were commanded by Nigerians.

During the period, while the troop strength of UNMIL was I4,824 from 49 troop contributing countries (UNMIL 20I5), Nigerian peacekeeping contingents constituted the bulk. Major General Salihu Zaway Uba, a Nigerian UNMIL Force Commander, noted that Nigeria 'deployed 37 infantry battalions, I3 signal units, 2I Formed Police Units, several military observers, United Nations Police, United Nations Volunteers, and international civilian staff to UNMIL' (Uba 20I6, p. 9). The Nigerian contingents played stabilizing role in Liberia. The Nigerian peacekeeping personnel in Liberia facilitated the consolidation of peace and peace-building process; provided humanitarian and development assistance through medical outreaches, teaching supports and donation of books to orphanages; provided executive protection for the Liberian President and Vice-President and other important government officials since 2003; provided cash escort, security of maximum correction facili- 
ty, protection for the main airport and urban patrols (Uba 20I6).

\section{President Taylor's asylum in Nigeria and the issues}

In line with Taylor's earlier decision to resign from office during a meeting with ECOWAS leaders, coupled with the insistence of Nigeria and the United States that President Taylor must quit, he eventually relinquished power to his Vice President as enshrined in the Liberian constitution on August II, 2003 (George 20I2). While some international observers wanted Taylor to immediately appear before the Court for prosecution (Lizza 2005), the government of President Obasanjo was mooting the idea of granting him asylum (Fawole 20I6; Nwolise 20I6; Ajayi 20I6). Taylor's departure from power and his acceptance of Nigeria's asylum offer - which brought an end to the carnage in Liberia - culminated in a Comprehensive Peace Agreement that was signed on August I8, 2003 in Accra after 75 days of negotiation. The Peace Agreement returned Liberia to the path of peace by providing for the establishment of a National Transitional Government that would replace the Interim Government (African Union 2004; Alli 20I2; George 20I2).

By welcoming Taylor to Nigeria, despite the burden of such a move, Nwolise (20I6) noted that President Olusegun Obasanjo was projecting Nigeria's 'big brother' role in Africa. Fawole (2016) maintained that it was the combination of President Obasanjo's global stature and Nigeria's own gravitas that convinced Taylor to accept the asylum. Nigeria's Taylor asylum was well received by President Bush of the United States of America. The American Ambassador to Nigeria during the period, Howard Jeter, reported to Congress in 2004 that Nigeria acted with the full knowledge and concurrence of the United States (Lizza 2005; Morgan 2003; Alli 2012). Explaining why the United States supported Nigeria's move, Lizza (2005) further noted that the career officers who dominated the State Department's Bureau of African Affairs had a Nigeria-centric view of West Africa. At that time, Nigeria was an increasing source of oil for the United States and Nigeria's military forces were needed for peacekeeping purposes across the continent.

Taylor's asylum generated some issues. While some wanted immediate trial, president Obasanjo was not kindly disposed to such idea (Nwolise 20I6). His thinking was that 'to turn Taylor over to the special Court without the support of the African states involved in Liberia would undermine Obasanjo's credibility as an African regional leader' (Campbell 20II, p. I30). As a matter of fact, Obasanjo's close associates were of the view that trying a former African head of state in an international court would create a prec- 
edent that would make arranging the voluntary departure of other tyrants more difficult in the future (Campbell 20II). Again, Nigeria's Taylor asylum was greeted with condemnation within the country. The loudest critics of the move, mostly members of the fourth estate of the realm, anchored their criticism on Taylor's brutal dictatorship and horrendous human rights abuses including the murder of two Nigerian journalists in 1989 , and his indictment for war crimes. Other critics labeled Nigeria as a country harboring war criminals (Oluyemi-Kusa 2007). Without dismissing the arguments of the critics, George (2OI2, p. 403) maintained that the overriding interests of the Liberian people and even of the sub-region were more paramount, and that the government of Nigeria 'would consider any request by a democratically elected government based on the wishes of the people of Liberia for the extradition of Taylor'.

Furthermore, the handling of Taylor's asylum was a subject of serious scrutiny much like the offer of asylum itself. The terms of his exile included strict conformity with the laws of Nigeria; abstention from engaging in any subversive activities against Liberia and the host country; refraining from participating in the political activities of Liberia while on Nigeria's soil; and desisting from instigating military intervention in Liberia (George 20I2). Taylor however disregarded his terms of exile. He engaged in subversive activities by exchanging correspondences and maintaining lines of communication with his former aides via e-mails and telephone calls, for which the United States had to slam a travel ban on Liberians acting as couriers for Taylor. He was also accused of helping several political actors that would participate in the Liberian elections. Perhaps, more grievous was Taylor's alleged assassination attempt on the life of ailing President Lansana Conte of Guinea, a neighboring country that supported the rebel forces that successfully campaigned against Taylor's government (Lizza 2005).

There was also the negligence that led to Taylor's disappearance before his final arrest in the Nigerian-Cameroonian border. In defense of Nigeria however, President Obasanjo, while interacting with President Bush at the Oval Office in 2006 , disagreed with the negligence-theory in Nigeria's handling of Taylor. He claimed that if Nigeria was negligent or connived with Taylor to enable him evade trial, then his arrest would not have been possible (Administration of George W. Bush 2006). President Obasanjo's defense notwithstanding, The Nigerian security officer who was responsible for Taylor told the Court that the negligence-theory was valid after all. He maintained that Taylor's correspondences and phone calls were not monitored. He also reported that Taylor received visitors, and contrary to popular belief, Taylor was not under house arrest in Nigeria (Lizza 2005). Taylor's attempted escape 
from Nigeria threatened to fracture diplomatic relations between the Obasanjo government and Bush administration in the US (Campbell 20II).

\section{Post-conflict elections}

Furthermore, Nigeria played a decisive role in the period leading to the 2005 post-conflict elections in Liberia. The subject of post-conflict elections has assumed a position of importance in the scholarly literature and policy cycles. The thinking is that post-conflict elections are considered critical to the peace building process in war-ravaged countries (Gambari 2005; Kieh 20II). In the case of Liberia, there were concerns about the democratic process and the actual conduct of elections. Commenting on these concerns, Sawyer (2008) noted that the post-conflict environment in Liberia was not conducive to holding elections and that a serious programme of reconciliation and constitutional reforms should have preceded the holding of elections. Gambari (2005, p. 7) observed that preparations for elections were not only behind schedule, there were other threats to stability such as 'the reintegration of ex-combatants and refugees, the disaffection of unemployed youth, government workers and Taylor loyalists', which 'put a dark shadow over the outcome and success of the election'. As a result, preparations for elections triggered another round of crisis among political parties. To address the crisis, President Obasanjo of Nigeria invited the aggrieved party leaders to Abuja for a dialogue. During the Presidential run-off, President Obasanjo once again sent General Abdulsallam Abubakar as special mediator to douse the tension (Alli 20I2).

\section{Other knocks}

As telling as Nigeria's peace intervention in Liberia was, there were a number of problems one can identify with the efforts of President Obasanjo. First, it appeared Nigeria's intervention could be likened to 'hegemony on a shoestring' because the country lacked the required military and economic wherewithal to impose its will on Liberia 'without appeasing local warlords and procuring external logistical assistance' (Adebajo 2006, p. I7). A major factor responsible for this was the depletion of Nigeria's financial resources as a result of decades of mis-governance and mismanagement (Ogunsanwo 20I6; Nwolise 2016), as well as the degeneration of the country's military capacity despite its previous excellent military campaigns to promote peace continentally and globally (Eke 20I5). 
Second, as a result of Nigeria's financial burden, the country was becoming wary of regional peacekeeping. Thus, before Nigeria's military intervention in Liberia in August 2003, the country 'insisted - as a condition for deploying - that the UN should take over the force three months later and send troops from other countries' (Adebajo 2006, p. I7). Owing to Nigeria's economic weakness when Obasanjo came in as the country's civilian president, his administration was anxious rather to reduce Nigeria's 'external commitments and to act whenever possible through multilateral institutions' (Lliffe 20II, p. 2I7).

Third, as argued by Obi (2009), the rehatting of ECOMOG forces as UN peacekeepers on October I, 2003 also gave birth to some issues. While the idea of 'African solutions to African problems' that also necessitated Nigeria's intervention was commendable, the transfer of ECOMIL's authority to UNMIL exposed the limitations and weaknesses of such idea at the time. The logistical and operational challenges faced by ECOMIL meant that the re-assignment of its troops to UNMIL was necessary after all. Apart from introducing African troops to new military doctrines, capabilities and logistical provisions, such change could reduce ECOWAS forces to 'playing second fiddle' to UN peacekeepers who would always like to take the credit after ECOWAS forces had done the spadework (Obi 2009; Osuntokun 2016).

Fourth, in spite of the UN zero tolerance policy on sexual exploitation and abuse by peacekeeping personnel, it has been observed that several Nigerian peacekeepers still engaged in sexual exploitation. It was estimated that thousands of children born to Liberian women were a product of sexual exploitation by Nigerian peacekeeping personnel. The number could be more staggering but for the usual under-reporting of cases of sexual abuse and exploitation (Butty 20I5). Some Nigerian peacekeepers were also accused of corruption, illegal diamond dealings, drug smuggling and other illicit activities (Regarding Rights 20I4).

\section{Conclusion}

Regardless of the criticisms, Fawole (20I6) argued that the restoration of peace to Liberia was a product of Nigeria's high level diplomacy under President Olusegun Obasanjo. In terms of the major efforts that led to the restoration of peace to Liberia, Nigeria played the leading roles. First, with respect to the deployment of peacekeeping personnel, Nigeria contributed the highest number of troops and produced mission commanders. Notable Nigerian military personnel such as Major General Festus Okonkwo, Major General Jo- 
seph Olorungbon Owonibi and Lieutenant General Chikadibia Isaac Obiakor played commanding roles in the theatres of operations under the banners of ECOMIL and UNMIL. Second, President Obasanjo played a major role in convincing President Taylor (who was the locus of the crisis) to quit office and accept Nigeria's offer of asylum. Taylor's departure from power and the signing of a Comprehensive Peace Agreement on August 18, 2003 brought an end to the crisis in the country. Third, Nigeria played a commendable role during the 2005 post-conflict elections in Liberia. Nigeria deployed its diplomatic resources to ensure the success of the elections (which were of crucial importance to sustainable peace in Liberia).

Liberian post-conflict political leaders have demonstrated their thankfulness to Nigeria. After the appointment of Mr Gyude Bryant as the Chairman of the National Transitional Government on August 2I 2003, Nigeria was the first country he visited in recognition and appreciation of the pivotal role that President Obasanjo played in the Liberian peace process (Alli 20I2; George 20I2). The immediate past president of Liberia - Mrs Ellen Johnson-Sirleaf - also acknowledged that Nigeria played the grandest role in the restoration of peace to Liberia. According to her, Liberians were overwhelmed with thankfulness and appreciation for Nigeria's commitments and sacrifices throughout the country's trying moment (Ndidi 20I7). As the key-informants would want us to accept, President Obasanjo's successful intervention in Liberia could be attributed to Nigeria's gravitas, manpower, military experience, and its well-oiled diplomatic machinery, particularly in the West African sub-region (Fawole 20I6; Nwolise 20I6; Osuntokun 20I6; Shehu 20I8).

\section{REFERENCES}

Adebajo, A. (2006). Prophets of Africa's renaissance: Nigeria and South Africa as regional hegemons. Nigerian Institute of International Affairs (NIIA) Occasional Paper Series No. 3. Lagos: NIIA.

Administration of George W. Bush (2006). Remarks following discussions with President Olusegun Obasanjo of Nigeria. Weekly compilation of Presidential documents, 29 March, 584-585.

African Union (2004). Report of the Chairperson of the Commission on the establishment of a continental peace and security architecture and the status of peace processes in Africa. Solemn launching of the Peace and Security Council, 9th Session, 25 May, Addis Ababa, Ethiopia.

African Leadership Magazine (20I6). Nigeria's peacekeeping efforts restored 
and sustained peace in Liberia - UN. 30 March. Available from: africanleadership.co.uk/nigerias-peacekeeping-efforts-restored-and-sustained-peace-in-liberia-u-n/ (accessed 20 June 20I7).

Agbu, O. (2007). Nigeria: How to benefit maximally from peace support operations. In: A. Ogomudia, ed. Peace support operations, command and professionalism: challenges for the Nigerian armed forces in the 21st century and beyond. Ibadan: Gold Press Limited, 212-232.

Ajayi, K. (2016). Author's personal interview with Professor Kunle Ajayi, Ekiti State University (EKSU), Ado-Ekiti, Ekiti State, 2I July.

Akinboye, S. O. (20I6). Author's personal interview with Professor Solomon Akinboye, University of Lagos, Lagos, I2 August.

Akinterinwa, B.A. (2013). Vie internationale contemporaine, 2007-2012: reflections on Nigeria in a pluriverse world of decline and incline. Volume one: Nigeria and the challenges of nation-building. Lagos: NIIA.

Akintola, A.L. (2007). The Nigerian navy participation in peace support operations since I960. In: A. Ogomudia, ed. Peace support operations, command and professionalism: challenges for the Nigerian armed forces in the 21st century and beyond. Ibadan: Gold Press Limited, 68-87.

Alli, W.O. (2012). The role of Nigeria in regional security policy. Abuja, Nigeria: Friedrich-Ebert-Stiftung.

BBC News (2003). The perils of Liberian peacekeeping. August 4. Available from: News.bbc.co.uk/I/hi/world/africa/3II3009.stm (accessed 20 June 20I7).

Boas, M. (20I4). 'Hunting ghosts of a difficult past': the International Crisis Group and the production of 'crisis knowledge' in the Mano River Basin wars. Third World Quarterly, 35(4), 652-668.

Butty, J. (20I5). UN peacekeepers in Liberia accused of buying sex. VOA News, June I2. Available from: https://www.voanews.com/a/alleged-sexbuying-by-un-peacekeepers/28I8895.html (accessed 20 June 20I7).

Call, C.T. (2010). Liberia's war recurrence: grievance over greed. Civil Wars, I2(4), 347-369.

Campbell, J. (20II). Nigeria dancing on the brink. New York: Rowman and Littlefield Publishers, Inc.

CNN International (2003). UN votes to send peacekeepers to Liberia. 2 August. Available from: edition.cnn.com/2003/WORLD/africa/o8/or/un.liberia/index.html (accessed 20 June 20I7).

Dukule, A.W. (2005). Nigeria Obasanjo hijacks Liberia elections. The Perspective, August 8. Atlanta, Georgia. Available from: www.theperspective. 
org/articles/080820050I.html (accessed 20 June 20I7).

Eke, S.J. (20I5). Why this charity begins abroad: comparing Nigeria's peacekeeping undertakings and domestic counter-insurgency operations. The Round Table, I04(3), 28I-296.

Fawole, W.A. (2000). Obasanjo's foreign policy under democratic rule: Nigeria's return to global reckoning? Nigerian Journal of International Affairs, 26(2), 20-40.

Fawole, W. A. (2016). Author's personal interview with Professor Alade Fawole, Obafemi Awolowo University (OAU), Ife, Osun State, 7 July.

Gambari, I.A. (2005). Building peace in Liberia: tough assignment or a lost cause? Welcome and keynote remarks at the School of International and Public Affairs (SIPA), Columbia University, New York, 8 April.

Gbor, J.W.T. (2007). The Nigerian army in peace support operations since I960. In: A. Ogomudia, ed. Peace support operations, command and professionalism: challenges for the Nigerian armed forces in the 21st century and beyond. Ibadan: Gold Press Limited, 6o-67.

George, O.O. (20I2). From rookie to mandarin: the memoirs of a second generation diplomat. Ibadan: Bolytag International Publishers.

Independent Online (I999). Nigeria spent R48-billion in Liberia. Monday October 25. Available from: https://www.iol.co.za/news/africa/nigeria-spent-r48-billion-in-liberia-I7435 (accessed 20 June 20I7).

Johnson Sirleaf, E. (I99I). The causes and consequences of the Liberian civil war. International Review, Spring, 32-35.

Kieh, G.K. (2009). The roots of the second Liberian civil war. International Journal of World Peace, XXVI(I), 7-30.

Kieh, G.K. (20II). Warlords, politicians and the post-first civil war election in Liberia. African and Asian Studies, Io, 83-99.

Kieh, G.K. (20I2). Neo-colonialism: American foreign policy and the first Liberian civil war. The Journal of Pan African Studies, 5(I), I64-I84.

Lewu, J.J. (2018). Author's personal interview with Ambassador Jaiyeola Joseph Lewu, Kabba, Kogi State, 5 August.

Lizza, R. (2005). White House Watch: Charles at large. The New Republic, 25 April.

Lliffe, J. (20II). Obasanjo, Nigeria and the world. USA: Boydell and Brewer Inc. Morgan, H. (2003). Peacekeeping, Nigeria's style: bad company. The New Republic, I8 \& 25 August.

Munive, J. (20II). A political economic history of the Liberian state, forced 
labour and armed mobilization. Journal of Agrarian Change, II(3), 357376.

Musa, S. (2010). Nigeria in international peacekeeping. In: O.C. Eze, ed. Beyond fifty years of Nigeria's foreign policy: issues, challenges and prospects. Lagos: NIIA, 293-3I0.

Nwolise, O.B.C. (2007). Peace support missions as means to six ends: But what benefits for Nigeria since I960? In: A. Ogomudia, ed. Peace support operations, command and professionalism: challenges for the Nigerian armed forces in the 21st century and beyond. Ibadan: Gold Press Limited, 200-2II.

Nwolise, O.B.C. (2016). Author's personal interview with Professor Osisioma Nwolise, University of Port Harcourt, Rivers State, 28 June.

Ndidi, O. (20I7). Nigeria played major role in Liberia's peace - Sirleaf. The Nation, Io November. Available from: thenationonlineng.net/Nigeria-played-major-role-liberias-peace-sirleaf/ (accessed 22 October 20I8).

Obasanjo, O. (I999). Statement by His Excellency President Olusegun Obasanjo. Speech presented at the consultative meeting on Conference on Security, Stability, Development and Cooperation in Africa (CSSDCA), Abuja, 28 August.

Obasanjo, O. (2000a). "The global millennium challenge”. Address by President Olusegun Obasanjo at the UN Millennium Summit, New York, 8 September.

Obasanjo, O. (2000b). Peace, security and development. Speech by President Olusegun Obasanjo at the 36 th Ordinary Summit of the Organization of African Unity, Lome, Togo, 25 September.

Obasanjo, O. (2004). Acceptance speech by His Excellency, President Olusegun Obasanjo. Speech presented on his election as the Chairman of the African Union, 6 July.

Obasanjo, O. (2006). History will remember us for Opting for Peace. Address by his Excellency, President Olusegun Obasanjo on the celebration of peace and the Presidential parade to formally mark the withdrawal of Nigeria armed forces from the Bakassi Peninsula, 2I August.

Obasanjo, O. (2007). Foreword. In: A. Ogomudia, ed. Peace support operations, command and professionalism: challenges for the Nigerian armed forces in the 21st century and beyond. Ibadan: Gold Press Limited, xvii-xviii.

Obi, C.I. (2009). Economic Community of West African States on the ground: Comparing peacekeeping in Liberia, Sierra Leone, Guinea Bissau, 
and Cote d'Ivoire. African Security, 2, II9-I35.

Ogunsanwo, A. (2016). Author's personal interview with Ambassador (Professor) Alaba Ogunsanwo, Lead City University, Ibadan, Oyo State, September 8 .

Oluyemi-Kusa, D. (2007). Sacrifices of the Nigerian nation and armed forces in peace missions since I960. In: A. Ogomudia, ed. Peace support operations, command and professionalism: challenges for the Nigerian armed forces in the 21st century and beyond. Ibadan: Gold Press Limited, I37I63.

Oshewolo, S. (2018). Nigeria's peace interventions in Sao Tome and Principe and the Republic of Togo under President Olusegun Obasanjo. African Identities, I-I3. DOI: I0.I080/I4725843.2018.I467750.

Osuntokun, A. (2016). Author's personal interview with Ambassador (Professor) Akinjide Osuntokun, Ilorin, Kwara State, June I2.

Regarding Rights (20I4). Tainted UN peacekeepers: reportage from the ground. 29 August. Available from: http://asiapacific.anu.edu.au/regarding-rights/2014/08/29/tainted-un-peacekeepers-reportage-from-theground/ (accessed 20 June 20I7).

Sawyer, A. (2008). Emerging patterns in Liberia's post-conflict politics: observations from the 2005 elections. African Affairs, I07(427), I77-I99.

Shehu, S.G. (2018). Author's personal interview with retired Captain Sadeeq Garba Shehu, 26 July.

The Liberian Connection, (nd). Who's who of the peacekeeping effort in Liberia. Monrovia, Liberia: The Liberian Connection (TLC) Africa Internet Magazine. Retrieved from www.tlcafrica.com/unmil.htm

The Perspective (2002). ULAA's report on Abuja peace and reconciliation conference. 29 March. Available from: www.theperspective.org/ulaareport. html (accessed 20 June 20I7).

The Perspective (2003). Profile of ECOMIL force commander Festus Okechukwu Okonkwo. 25 September. Available from: www.theperspective.org//inquirer/festusokonkwo.html (accessed 20 June 20I7).

Saliu, H.A. \& Oshewolo, S. (20I8). "Nigeria in African affairs: hegemonic and altruistic considerations". The Round Table, I07(3), 29I-305. DOI: I0.1080/00358533.2018.1476095.

Uba, S.Z. (2016). An appraisal of Nigeria's participation in UNMIL peacekeeping. A paper presented at the Ministry of Defence Nigeria peace support operations seminar, National Defence College, Abuja, I2-I6 June.

United Nations (2005). Secretary-General appoints Lieutenant-General Joseph 
Owonibi (Nigeria) as force commander of the United Nations mission in Liberia. United Nations meeting coverage and press releases, January I2. Available from: https://www.un.org/press/en/2005/sga902.doc. htm (accessed 20 June 20I7).

United Nations Security Council (2003a). Security Council Resolution 1497 (2003) (On the situation in Liberia). I August. Available from: http:// www.refworld.org/docid/3f45dbec7.html (accessed 20 June 20I7).

United Nations Security Council (2003b). Security Council Resolution 1509 (2003) (On establishment of UNMIL). I9 September. Available from: http://www.refworld.org/docid/3f8d304d4.html (accessed 20 June 20I7).

United Nations Mission in Liberia (UNMIL) (20I5). Military. Available from: https://unmil.unmissions.org/military-o (accessed 22 October 20I8).

Yoroms, G. (2005). The second Liberian peace process and the problem of post-conflict peace building in West Africa: some contending issues and interests. IFRA Special Research Issue, I, 79-92.

\begin{abstract}
Although peace operations have been a major instrument of Nigeria's foreign policy continentally and globally, this study analyzed the country's peace campaigns in Liberia under president Olusegun Obasanjo. The paper observed inter alia that Obasanjo's peace efforts in Liberia were influenced by his recognition of Nigeria as a leading actor in the stabilization efforts in the region. While there were some encumbrances, Nigeria's peace campaigns in Liberia were successful as revealed by the data sources. Nigeria's major accomplishments included the eventual signing of a comprehensive peace agreement in 2003 that brought an end to the carnage in the country, offer of asylum to Taylor, and the 2005 post-conflict elections. These accomplishments could be attributed to President Obasanjo's gravitas and Nigeria's well-oiled diplomatic machinery in the West African sub-region. To arrive at this conclusion, the paper adopted the secondary data sources and interview technique for the purpose of data collection, and descriptive thematic analysis.
\end{abstract}

\title{
KEYWORDS
}

Peacekeeping; Mediation; President Obasanjo; Nigeria; Liberia; Africa

Received on November 24, 2018 Approved on February 15, 2019 